\title{
ENTRE LA IMAGEN Y EL CONCEPTO: WALTER BENJAMIN Y JOSEPH KOSUTH
}

\author{
Tatiana Staroselsky \\ Universidad Nacional de La Plata \\ Consejo Nacional de Investigaciones Científicas y Técnicas \\ bttp://dx.doi.org/10.15304/ag.39.1.5676
}

\section{Resumen}

Este trabajo se propone indagar la relación entre la obra del filósofo Walter Benjamin y parte de la producción del artista conceptual Joseph Kosuth, partiendo de la hipótesis de que ambos representan un desplazamiento de sus disciplinas hacia un cruce de caminos entre el arte y la filosofía. En efecto, mientras en Benjamin la filosofía va más allá del concepto para alcanzar la imagen, en Kosuth el arte se apropia de las palabras y evita toda representación visual del mundo.

Palabras clave: Walter Benjamin, Joseph Kosuth, filosofía, arte conceptual, experiencia.

\section{Abstract}

This article aims to investigate the relationship between the work of the philosopher Walter Benjamin and part of the production of the conceptual artist Joseph Kosuth. It is argued that both represent a displacement of their disciplines towards a crossroads between art and philosophy. In fact, while in Benjamin's works philosophy goes beyond concept to explore the image, in Kosuth art appropriates the words and avoids any visual representation of the world.

Keywords: Walter Benjamin, Joseph Kosuth, philosophy, conceptual art, experience.

Recibido: 13/12/2018. Aceptado: 24/01/2019. 


\section{Introducción}

El corrimiento, borramiento o cuestionamiento de los límites disciplinares se configura como un rasgo propio de la época contemporánea: como señala García Canclini, el arte adquiere funciones sociales, políticas y económicas y explora su capacidad de reflexionar acerca del mundo (García Canclini, 2010, p. 29). Las ciencias sociales y la filosofía, por su parte, sofocadas por las estructuras y los métodos que las atraviesan, encuentran en el arte ya no sólo un tema o un objeto de reflexión, sino más bien un lugar al que ir a pensar.

El punto de partida de este trabajo será, efectivamente, el escenario que arroja lo que García Canclini denomina "giro transdisciplinario intermedial y globalizado" (García Canclini, 2010, p. 40). La hipótesis que nos guía es que, mientras que ya en los comienzos del siglo xx el arte se aleja de la tiranía de la imagen para acercarse al concepto y buscar allí modos nuevos de decir (Genette, 1997), cuestionando fuertemente su propia naturaleza, la filosofía hace lo suyo, escapándose del marco del concepto que la caracterizó por más de dos mil quinientos años y buscando en la producción de imágenes un camino de actualización.

Como menciona Laddaga, lo que se explora, ya a partir de fin del siglo XVIII, es "la capacidad de las artes para proponerse como un sitio de exploración de las insuficiencias y potencialidades de la vida común" (Laddaga, 2006 , p. 8), y para esto se ponen en marcha "modos posdiscliplinarios de operar" (Laddaga, 2006, p. 19). Agregaremos que, en la filosofía, y particularmente en la obra de Walter Benjamin, se da un movimiento similar, en tanto este filósofo berlinés es consciente de que nos encontramos "en medio de un enorme proceso de refundición de las actuales formas literarias, en el que muchas de las contraposiciones en las que estamos acostumbrados a pensar podrían ya perder toda su fuerza" (Benjamin, 2009, p. 301).

En este contexto, y sin la pretensión de tratar exhaustivamente los temas que nos convocan (la cuestión de la imagen en Benjamin, la relación del arte conceptual con los planteamientos filosóficos), nuestro objetivo es ofrecer una lectura de la relación entre Benjamin y Kosuth en tanto resulta productiva para poner en cuestión los modos tradicionales, disciplinares de operar, dando cuenta de algunas de las limitaciones que les son propias y de la potencialidad de ciertas formas de decir para generar experiencias no sólo interesantes sino también epistemológicamente valiosas.

Para esto, trabajaremos principalmente con cuatro fuentes. Por un lado, centraremos nuestra atención en parte de la obra de Benjamin, especialmen- 
te en "El autor como productor", de 1934, como marco teórico ${ }^{1}$, y Calle de mano única, de 1928, en tanto resulta un ejemplo paradigmático de una producción filosófica que se acerca a la imagen y en la que la cuestión de la exposición resulta central. El filósofo se colocaría, en este nuevo escenario y como el propio Benjamin dice en el "Prólogo epistemocrítico" a El origen del Trauerspiel alemán, publicado también en $1928^{2}$, entre el investigador y el artista. Por otro lado, abordaremos parte de la obra de Joseph Kosuth, en tanto artista que vincula su obra a la filosofía y que explora allí renovaciones posibles del lenguaje artístico. Nos centraremos, como en el caso de Benjamin, en un texto teórico, "Art after Philosophy”, de 1969, e indagaremos asimismo parte de su producción artística. Específicamente, nos referiremos a BERLINER CHRONIK, de 1994, instalación en la que Kosuth se basa en la obra de Benjamin.

Organizaremos el trabajo de la siguiente manera: analizaremos en la primera sección, y circunscribiéndonos a los textos mencionados, y a algunos otros escritos afines, las propuestas teóricas de ambos pensadores, que se preguntaron por los modos de proceder en sus disciplinas y que tienen en común haber significado una cierta renovación o al menos una propuesta innovadora en sus áreas, que en ambos casos tiene un marcado tono multidiscliplinar. En la segunda sección nos concentraremos en las producciones artísticas/filosóficas de Kosuth y Benjamin ya mencionadas para dar cuenta del movimiento que significan en sus respectivas áreas. Ambos recorren, de alguna manera, el mismo camino, pero lo hacen en direcciones opuestas: Benjamin operando una ruptura en la hegemonía del concepto en la filosofía y dirigiéndose hacia la imagen, y Kosuth encontrando en el concepto una vía para la desmaterialización del arte.

\section{Benjamin y Kosuth acerca de los límites disciplinares}

Tanto Walter Benjamin como Joseph Kosuth dieron indicaciones teóricas y metodológicas que resultan muy útiles para pensar su obra y para acceder

\footnotetext{
${ }^{1}$ En función de esclarecer algunos conceptos y de dar cuenta de algunas problemáticas que, si bien aparecen en el texto de esta conferencia, atraviesan más ampliamente la obra de Benjamin, trabajaremos con El origen del Trauerspiel alemán, en cuyo prólogo, como veremos, la cuestión de la exposición resulta central. Asimismo, nos referiremos a "Experiencia y pobreza", en tanto la conciencia de la crisis de la experiencia y de la tradición que allí se diagnostica signa la filosofía de Benjamin muy profundamente.

${ }^{2}$ Si bien El origen del Trauerspiel alemán se publica en 1928, es redactado por Benjamin en 1925 como tesis de habilitación docente.
} 
a sus particulares modos de comprender las tareas, en el caso de Kosuth del artista y en el caso de Benjamin del filósofo o, más ampliamente, del autor.

Benjamin deja muy clara su posición con respecto al rol de los intelectuales y artistas en la sociedad en la conferencia titulada "El autor como productor" ${ }^{3}$. En este texto el filósofo hace, en sus propias palabras, una "crítica política literaria" [politischen Literaturkritik] (Benjamin, 2009, p. 298) y comienza dando un paso cuya importancia no habría que perder de vista: se refiere a la escritura como actividad. Al hacerlo, desarticula categorías para pensar la producción artística/intelectual profundamente arraigadas, como los pares binarios forma-contenido de la obra o el que se abre entre la tendencia política de la obra y su calidad — digamos - técnica, en un sentido que será bastante próximo al movimiento que realizará Kosuth en los años 60 para el plano de arte.

Asimismo, Benjamin hace un movimiento de cambio de foco: no se pregunta por el lugar que ideológicamente ocupan la obra o el autor (qué defiende, qué critica, si es, en su contenido o en su mensaje, reaccionaria o revolucionaria), sino que apunta a la posición de la obra como tal en las relaciones sociales de producción literaria. Hace foco entonces en la técnica, la hechura, en fin, en la producción. Este punto, como ampliaremos más adelante, también mantiene un cierto paralelismo con las ideas de Kosuth, para quien el arte conceptual fue aquel que logró, no ya decir cosas distintas con el mismo lenguaje, sino cambiar el lenguaje con el que tradicionalmente se producían significados.

Benjamin afirma que lo que determina el lugar del intelectual en la lucha de clases es su posición en el proceso de producción, por lo que éste debe trabajar no sobre su conciencia de clase sino sobre su técnica productiva.

En el texto de la conferencia que nos ocupa, Benjamin sostiene que los géneros literarios/filosóficos son temporales e indica la necesidad de que sean repensados teniendo en cuenta las realidades técnicas de nuestra situación actual (Benjamin, 2009, p. 301), en tanto la época está signada por un proceso de fusión en el que las formas tradicionales han perdido actualidad y potencia. Esta crisis de los géneros literarios y de los formatos que nos habían servido para pensar, sumada a la crisis de la experiencia diagnosticada sólo un año antes en "Experiencia y pobreza", constituye el trasfondo en el marco del cual Benjamin desarrolla su propia obra, que se despliega

${ }^{3}$ Como se indica en la edición en español de Abada (Benjamin, 2009, p. 297, nota I), el título corresponde en realidad a una conferencia que Benjamin preparó para pronunciar en el Instituto para el Estudio del Fascismo durante su exilio en París, en 1934, pero cuya lectura finalmente no habría tenido lugar. 
como una búsqueda de dar respuesta a esta situación desde la práctica, y más aún, desde la técnica literaria, desde la experimentación con la propia escritura. Nada, y Benjamin lo sabe, podrá lograrse en las trincheras de la intelectualidad "si el escritor experimenta su solidaridad con el proletariado solamente en su mentalidad, y no en tanto ya que productor" (Benjamin, 2009 , p. 303).

El escritor como hombre de espíritu es, para él, parte de una casta que pretende definirse según sus opiniones, esto es, de manera no materialista, sin prestar atención al lugar real que ocupa en el proceso productivo en el que su trabajo se inserta.

El autor deberá centrarse no ya en el producto, sino ahora en la acción misma de escribir entendida como producción, y mejorar el aparato con el que produce: tomar, en sentido fuerte, los medios de producción en lugar de limitarse simplemente a utilizarlos. Para Benjamin, debemos descentrar la atención de lo que el escritor dice —en la constelación de los temas, las opiniones, los debates, el contenido- y dirigirla al proceso real de producción de los textos.

La reflexión sobre la relación entre la forma y el contenido de la obra se anticipa algunos años antes en el "Prólogo epistemocrítico" que precede al libro sobre El origen del Trauerspiel alemán. Allí, Benjamin se refiere a la cuestión de la exposición [Darstellung], en tanto "es propio de la escritura filosófica enfrentarse de nuevo, a cada viraje, con la cuestión de la exposición" (Benjamin, 2010, p. 223) y la coloca como aquello que une a la filosofía con el arte. En ese contexto, plantea que "ha sido corriente colocar al filósofo demasiado cerca del investigador, a menudo en la que es su versión más limitada. Ninguno parecía ser lugar, en la tarea propia del filósofo, para atender a la exposición" (Benjamin, 2010, p. 228). En su obra, en cambio, el modo de exposición resulta central, en tanto su filosofía surge en la dialéctica entre forma y contenido, inseparables en sus textos, que se inscriben y no se inscriben, a la vez, en la filosofía y en el arte.

Conviene detenernos brevemente en algunas especificaciones conceptuales que aporta el escrito sobre el Tranerspiel.

Un primer concepto que resulta relevante atender es justamente el de “exposición”, con el que Benjamin trabaja en el Prólogo. Lo que se persigue en filosofía es, argumenta el filósofo berlinés, la exposición de la verdad, que se distingue del conocimiento. En efecto, mientras que "el conocimiento es un haber" (Benjamin, 2010, p. 225), esto es, posee el "carácter de la posesión” (Benjamin, 2010, p. 226), la verdad no puede ser poseída, sino que es del orden de aquello que se manifiesta o se expone. Asimismo, y 
mientras que el conocimiento es intencional y opera con conceptos (es decir, mediante subsunciones y síntesis), "la verdad es la muerte de la intención" (Benjamin, 2010, p. 231) y se expresa en ideas, que "le están dadas a la observación” (Benjamin, 2010, p. 226) ${ }^{4}$.

La filosofía, entonces, no tendrá que ver con el conocimiento, en el marco del cual "se trata siempre de saber cuál es el camino correcto, el método, que le permite al sujeto apropiarse del objeto" (Gagnebin, 2005, p. 189), sino con la verdad, cuyo método es el rodeo $^{6}$. El ejercicio de la filosofía deberá consistir, entonces, para Benjamin, en el abandono de dos actitudes que la signaron tradicionalmente, como expone muy claramente Gagnebin:

Doble renuncia: al ideal del camino recto y directo en provecho de los desvíos, de la errancia; y renuncia también al curso ininterrumpido de la intención, esto es, renuncia a la obediencia a los mandamientos de la voluntad subjetiva del autor. ¿En provecho de qué? De un recomenzar y de un incesante volver a tomar aliento en torno a la Sache selbst, a la cosa misma (to on ontôs), centro ordenador y simultáneamente inaccesible del pensar y del decir (Gagnebin, 2005, p. 188).

El énfasis en el modo de exposición recorre, como señala Steiner (2002, p. 276) la obra de Benjamin acompañando sus transformaciones. En los años 30, y especialmente en el marco del proyecto de los pasajes, esta inquietud se ligará al montaje y a la construcción, adquiriendo la forma de la conocida fórmula metodológica del filósofo alemán: "Nada que decir, sólo mostrar" (Benjamin, 2013, p. 739).

La segunda aclaración conceptual que resulta relevante para nuestro trabajo gira en torno al concepto de alegoría, y a su distinción con respecto al simbolo, de la que Benjamin se ocupa en la segunda parte del libro, en tanto es central para comprender la dialéctica entre forma y contenido tal y como él la presenta.

${ }^{4}$ Aun así, cabe aclarar que Benjamin no rechaza los conceptos, en tanto considera que pueden ser un medio para la exposición de las ideas. En sus palabras: "La diferenciación en conceptos queda a salvo de cualquier sospecha de puntillismo destructivo exclusivamente allí donde se haya propuesto ese rescate de los fenómenos en las ideas (...) Gracias a su papel de mediadores, los conceptos permiten a los fenómenos participar del ser de las ideas. Y justamente este papel de mediadores los hace aptos para aquella otra tarea, que resulta igualmente originaria, correspondiente a la filosofía, a saber, la exposición de las ideas” (Benjamin, 2010, pp. 229-230). Sobre el concepto benjaminiano de idea remitimos a Holz (2014).

5 En todos los casos, las traducciones del artículo de Gagnebin (originalmente en portugués) son nuestras.

${ }^{6}$ Sobre esta máxima benjaminiana resulta muy interesante el artículo de Steiner (2002) “'Das Höchste wäre: zu begreifen, dass alles Factische schon Theorie ist'. Walter Benjamin liest Goethe“. Allí, el autor trabaja con la máxima de Goethe tras la cual titula el artículo y su recepción por parte de Benjamin. 
Y es que en la forma alegórica, que es la forma de expresión del Tranerspiel, se revela lo histórico y lo material (Lindner, 2014, p. 24), pero no como un mero contenido que es representado ${ }^{7}$ a través de esa forma pero podría serlo mediante cualquier otra ${ }^{8}$. La alegoría no es "una mera sobrecodificación que realzaría la profundidad (y autoridad) del misterio: la alegoría es el trabajo desde la superficie misma de los fragmentos” (García, 2010, p. 171). Continuando con la interpretación de García, que compartimos:

Toda la crítica benjaminiana al concepto tradicional (clásico-romántico) de alegoría insistía en que ella no es una mera imagen ilustrativa que recubriría, como un velo, una abstracción conceptual, un precepto moral, un contenido previo y meramente recubierto por la imagen, pero enunciable de manera transparente (simbólica). La alegoría no se juega en la dialéctica entre velo (imagen) y profundidad interpretativa (precepto moral), sino en la diseminación de fragmentos y el trabajo de desciframiento (García, 2010, pp. 170-171).

La alegoría funciona, entonces, como una escritura, "o mejor: como una escritura que tiende a la imagen" (Lindner, 2014, p. 35), y que en el caso del barroco expresa

la constitución sufriente de su propio tiempo, el desgarramiento de una naturaleza mortificada que vivencia el alejamiento de la divinidad, esto es, su propia orfandad como condición insuperable. Y es eso mismo lo que ellas expresan: la imposible clausura de una realidad desolada que significa siempre y solo su muerte. Por tanto, expresar no implica representar, reunificar o reconciliar sino hacer justicia al darse de un mundo quebrado (Espinosa, 2017, p. 53).

${ }^{7}$ Sobre el concepto de representación, y el modo en que Benjamin se distancia de él, puede resultar esclarecedora la explicación de Jean-Marie Gagnebin, suscitada por una elección terminológica del traductor del texto al portugués. En el artículo "Do conceito de Darstellung em Walter Benjamin ou verdade e beleza" dice la autora: "[l]a palabra Darstellung —utilizada por Benjamin para caracterizar la escritura filosófica- no puede (...) ser traducida por "representación” (...), ni el verbo darstellen puede ser traducido por "representar". Aun cuando esa traducción pueda ser legítima en otro contexto, produce, en el texto en cuestión, un contrasentido, porque puede llevar a la conclusión de que Benjamin se inscribe en la línea de la filosofía de la representación, en el sentido clásico de representación mental de objetos exteriores al sujeto, de la que Benjamin toma distancia" (Gagnebin, 2005, p. 184. La traducción es nuestra).

${ }^{8}$ Los ecos de la teoría del lenguaje que Benjamin desarrolla en sus escritos juveniles se dejan oír aquí muy claramente. En "Sobre el lenguaje en cuanto tal y sobre el lenguaje del hombre", redactado en 1916, distingue entre la función representativa del lenguaje (en la que el lenguaje es instrumentalizado y utilizado para representar algo que le es externo y para comunicar, así, un contenido) y la expresiva, en la que este rol mediador desaparece y en la que en el lenguaje (y no ya mediante el lenguaje), y típicamente en el nombre, el ser espiritual de las cosas, que es a su vez lenguaje, se comunica. La concepción burguesa del lenguaje, que lo entiende como "un instrumento de comunicación del sujeto" (Abadi, 2015, p. 198), es rechazada en pos de una concepción que Benjamin no vacila en llamar mágica y que se nutre de elementos teológicos. 
Mientras que el símbolo celebra típicamente la unión armoniosa entre significante y significado, la alegoría permite romper con esa ilusión de armonía y de totalidad, en tanto,

[c]uando el equilibrio entre significante y significado, núcleo del símbolo, es roto por una violencia que desaloja el sentido del mundo, los significantes cobran una materialidad en bruto que los reconduce a la ostensión de lo elemental de su materia sensible. En el grito de la inmanencia desnuda, phoné se desconecta de logos; sólo queda el chillido amorfo. Así sucede en la alegoría, y cuando la palabra se vacía resta el trozo amorfo, quedan los "áridos rebus" como modelo de una escritura (...) que, como pictograma, requiere ser leída (García, 2010, p. 168).

Benjamin rechaza la filosofía del arte de su época (Steiner, 2002) en tanto interpreta la manifestación de la idea siempre como símbolo, relegando la expresión alegórica a un segundo plano. En la segunda parte del libro critica esta ideología de lo simbólico; ideología que incluye a su vez una distinción antagónica entre símbolo y alegoría — "el discurso moderno e insostenible de la alegoría y el símbolo” (Benjamin, 2010, p. 378)— con la incomprensión de este último y el rechazo de la primera (Benjamin, 2010, p. 378).

Esta simplificación, y la incomprensión a la que lleva, afectan al modo en que la relación entre forma y contenido de una obra es comprendida. En palabras de Benjamin:

a falta de un auténtico temple dialéctico, en el análisis formal se pierde el contenido, y en la estética del contenido se pierde la forma. Pues este abuso, en efecto, tiene siempre lugar cuando en la obra artística se expresa la 'manifestación' de una 'idea' en cuanto 'símbolo' (Benjamin, 2010, p. 376).

En contra de esta tradición, Benjamin buscará rescatar la alegoría (así como busca salvar al barroco mismo), reinterpretándola. Pues "la alegoría (...) no es una técnica lúdica de producción de imágenes, sino que es expresión, tal como es sin duda expresión el lenguaje, y también la escritura" (Benjamin, 2010, p. 379).

Aun cuando las ideas del libro sobre el Tranerspiel raramente son leídas en consonancia con los postulados, más cercanos al marxismo, que Benjamin presenta en "El autor como productor", hay importantes puntos de contacto. En ambos casos la relación entre la forma y el contenido de la obra es repensada, y el aislamiento de ambas esferas de análisis en términos dicotómicos es rechazado.

En el texto más temprano este tópico es trabajado en función de operar un rescate de la alegoría como forma de expresión del Trauerspiel y como única forma capaz de exponer aquello que el Tranerspiel busca mostrar. 
A su vez, la forma de exposición, desde siempre más y mejor atendida en el arte, es presentada como problema filosófico y atendida en tanto problema epistemológico.

En "El autor como productor", un Benjamin ya cercano al materialismo histórico revisita estos tópicos en tanto le permiten cuestionar un tipo de compromiso político que se centra de modo exclusivo en el contenido de la obra, cuando no en formas que recuerdan a la alegoría en su comprensión más limitada, esto es, aquella que artificialmente esconde su mensaje tras un velo con una intención meramente didáctica.

En este contexto, el rebasamiento de los límites disciplinares impuestos a la actividad intelectual que propone Benjamin en el texto de su conferencia de 1934 puede ser leído como recuperando su preocupación por la cuestión de la exposición, que la filosofía ha descuidado, pero con la que se topa a cada giro y que debe ser repensada.

En efecto y como indica el berlinés en "El autor como productor", una de las maneras de transformar los aparatos de producción sería la experimentación técnica con los géneros literarios, o en sus palabras "la superación de las competencias en el proceso de producción espiritual" (Benjamin, 2009, p. 307), y especialmente el intento de "superar una de esas contraposiciones que encadenan la producción de inteligencia. En este caso se trata de la barrera existente entre escritura e imagen" (Benjamin, 2009, p. 307).

Este punto nos parece central, en tanto da cuenta teóricamente de un ejercicio de producción que Benjamin había llevado a cabo algunos años antes en Calle de mano única, donde publica breves instantáneas filosóficas que tienen la particularidad de presentarse como imágenes de pensamiento. Aun cuando a primera vista no es más que un ejercicio de experimentación vanguardista, resulta importante recuperar este libro como una apuesta por presentar ideas filosóficas en un lenguaje que se acerca a la imagen, atendiendo a la exposición de modo tal que la verdad pueda al menos relampaguear ${ }^{10}$.

${ }^{9}$ Si bien en este trabajo nos centramos sólo en algunos matices y sentidos del motivo de la imagen en Benjamin, en función de llamar la atención sobre el cruce entre los lenguajes del arte y la filosofía que se pone en juego en el siglo xx, el tema es inagotable y ha sido exhaustivamente estudiado. En especial, recomendamos para este tema la lectura de Weigel (1999), Zumbusch (2004), y, sobre el concepto — clave en la obra de Benjamin- de imagen dialéctica, Hillach (2014).

${ }^{10}$ Calle de mano única, publicado el mismo año que el libro sobre el Tranerspiel, y si bien a simple vista puede no parecerlo, comparte con el texto de la frustrada habilitación de Benjamin algunos rasgos importantes, como ya notara Kracauer (1995). 
Asimismo, el llamado benjaminiano a repensar o redefinir el límite entre escritura e imagen tiene interesantes puntos de contacto con el desarrollo del arte en el siglo xx, y aun con derivas de la producción artística que él no pudo conocer. El caso de Kosuth y, en general, del arte conceptual, de su alejamiento del modelo de la representación y de su acercamiento al trabajo con las palabras, resulta especialmente relevante.

Nos referiremos ahora al marco teórico que el mismo Kosuth escribe para su obra, para analizar la relación entre la aproximación que este autor propone del arte al mundo del lenguaje (y su alejamiento del soporte visual y, concretamente, de la imagen) y el acercamiento que realiza Benjamin de la filosofía al lenguaje visual.

La obra de Joseph Kosuth se enmarca, como menciona Ana María Guasch (2001), dentro de lo que se denomina "arte conceptual”, que, lejos de ser un estilo artístico definible, puede ser comprendido como un proceso histórico y artístico complejo que tiene, por un lado, antecedentes muy relevantes, como el arte minimal y el arte concepto, y, por el otro, consecuencias y prolongaciones muy significativas. En efecto, el arte conceptual da lugar a otros movimientos y surgimientos, tanto en el ámbito de la producción artística como en el de la reflexión teórica sobre el arte, que se enmarcan en el contexto de una redefinición radical del campo artístico que se prolonga hasta nuestros días y que no parece tener fin. Un proceso que resulta central en este desarrollo, y en el que nos detendremos especialmente, es el de la desmaterialización del arte, cuyo comienzo podemos situar, siguiendo a Guasch, en los primeros movimientos de oposición a la escuela formalista de Nueva York, y para el cual Kosuth, como artista y como teórico, no puede dejar de ser considerado. También para Benjamin Buchloh, el arte conceptual significa "la más rigurosa eliminación de la visualidad y de las definiciones tradicionales de la representación” (Buchloh, 1990, p. 107. La traducción es nuestra).

Kosuth participó, junto a otros artistas, en la primera exposición de arte conceptual, que tuvo lugar en la Dwan Gallery de Nueva York en junio de 1967, y que se llamó "Language to be looked at and/ or Thing to be read", y publicó su célebre ensayo “Art after Philosophy” en 1969. En la exposición, el artista presentó una serie de obras basadas en la relación entre los objetos materiales, las palabras que los nombran y las definiciones de estas palabras. Luego de esta primera exposición se sucedieron muchas otras, tanto grupales como individuales y, como es esperable, la obra de Kosuth, con eje en la redefinición constante de la naturaleza y la función del arte, 
siguió mudando de formato y de contenido, aun cuando mantuvo siempre un mismo ímpetu y una misma intención.

Donald Karshan, que escribió el catálogo de otra exposición en la que Kosuth participó ("Conceptual Art and Conceptual Aspects", de 1970) sostiene que "el arte del post-objeto está basado en la premisa de que la idea de arte se ha extendido más allá del objeto o de la experiencia visual al ámbito de la investigación" (citado por Guasch, 2001, p. 173). En efecto, el arte se separa de la tradicional experiencia estética y se aloja en la idea o en el concepto para hacer posibles experiencias de un tipo nuevo.

En "Art after Philosophy", su programático escrito de 1969, Kosuth sostiene que "hemos de juzgar a los artistas en función de su modo y capacidad de cuestionar la naturaleza del arte" (Kosuth, 1991, p. 18). En este sentido habría, para Kosuth, un antes y un después de la obra de Duchamp, en la medida en que este artista fue el primero en cuestionar el lenguaje del arte, que permanecía, antes de él, inalterado, mientras que después de su obra, particularmente de sus Ready-mades, cambió para siempre de un modo que ningún artista puede ignorar.

El escrito de Kosuth presenta varias tesis fuertes, algunas de las cuales son desarrolladas y explicadas por el autor, mientras que otras resultan más crípticas. Este es el caso, por ejemplo, de la idea del fin o la irrealidad de la filosofía, que Kosuth parece tomar del Tractatus logico-philosophicus de Ludwig Wittgenstein, publicado en 1923. Si bien Kosuth ofrece algunas razones para sostener la caída de la forma tradicional de filosofar (afirma que la filosofía dejó de ocuparse de lo no dicho; que ya no hay nada más que decir; que hay, a diferencia de otros momentos históricos, demasiada información), no queda claro por qué cree que la filosofía que se produce en su tiempo no debería ser llamada filosofía. La tesis de que "el siglo veinte trae un tiempo que podría ser llamado 'el fin de la filosofía y el comienzo del arte'" (Kosuth, 1991, p. 14) ${ }^{11}$, o al menos su primera afirmación —acerca del fin de la filosofía- no parece estar suficientemente justificada en el escrito, en tanto no se da una definición de filosofía que pueda ejercer de parámetro para determinar si una producción es o no filosófica. Por otro lado, mientras que sobre el arte se sostiene, citando a Don Judd, que "si alguien lo llama arte, es arte" (Kosuth, 1991, p. 17), no parece suceder lo mismo con la producción filosófica. Quizá Kosuth piense aquí como Danto, que en su diagnóstico acerca del "fin del arte" aclara:

\footnotetext{
${ }^{11}$ Todas las traducciones del texto de Kosuth son nuestras.
} 
yo también pienso en el arte en sí mismo como algo que nombra no tanto una práctica como un movimiento, o incluso un período, con marcadas fronteras temporales. Esto es, por supuesto, un dilatado movimiento o período, aunque hay una buena cantidad de movimientos o prolongados períodos históricos tan universalmente incorporados en la actividad humana que a veces olvidamos pensarlos históricamente, y una vez que lo hacemos, podemos imaginar de un modo u otro su final —el de la ciencia y la filosofía, por ejemplo-. Éstos se podrían extinguir sin que se desprenda de ello que las personas dejen de filosofar o hacer ciencia (Danto, 2010, p. 47).

Volveremos sobre este punto en las consideraciones finales del trabajo.

A partir de este diagnóstico de época, Kosuth se propone dos cosas: por un lado, analizar la función del arte y su viabilidad, y por el otro, ofrecer una explicación clara acerca de qué es el arte conceptual, en el que su producción se enmarca. Para ambos puntos será decisiva la diferencia que plantea entre arte y estética. Esta última "lidia con opiniones sobre la percepción del mundo en general” (Kosuth, 1991, p. 16), en la constelación del "gusto", y así, no se limita a los objetos considerados artísticos sino que emite juicios que los exceden, en tanto dichos juicios no toman en consideración la función del objeto sino sólo sus atributos físicos. El arte, en cambio, tiene que ver justamente con la función, y por eso comienza —en la opinión de Kosuth-con aquel episodio a partir del cual la pregunta acerca de la función del arte fue planteada: la presentación de los Ready-mades de Marcel Duchamp.

Aquello que hace a la obra de Duchamp tan relevante a los ojos del artista conceptual es el hecho de que, antes de él, "el lenguaje del arte permanecía inalterado, pero estaba diciendo cosas nuevas" (Kosuth, 1991, p. 18), mientras que, después de él, el arte se centra en trabajar sobre su propio lenguaje, dándose lenguajes nuevos, tras descubrir que "era posible hablar otro lenguaje y aun así hacer algo que tuviera sentido" (Kosuth, 1991, p. 18 ) en el campo del arte. Las nuevas producciones y los nuevos artistas, a partir de este cambio de paradigma, serán juzgados según cuán radicalmente sepan cuestionar la naturaleza del arte, lo que implica que su apreciación será conceptual y no ya estética. Este punto de la reflexión de Kosuth lo explica muy bien Genette, quien sostiene que las obras ya eran conceptuales antes de que el arte conceptual, así considerado, entrara en escena. Para él, hay una recepción conceptual y una recepción estética del arte, que exceden por mucho al arte conceptual, si bien éste ha sabido trabajar muy lúcidamente sobre esta distinción, y crear obras "cuyo objeto de inmanencia es (...) un concepto (...) y cuya manifestación puede ser ora una definición ora una ejecución” (Genette, 1997, p. 166). 
En la ampliación que realiza Genette del campo de aplicación del mote de "conceptual" para el arte, lo que hace conceptual a una obra es que el objeto es presentado

no en virtud de sus cualidades estéticas en el sentido corriente, sino, al contrario, en virtud del carácter crítico, paradójico, provocativo, polémico, sarcástico o simplemente humorístico que acompaña al acto de proponer como obra de arte un objeto o un acontecimiento cuyas propiedades suelen considerarse no artísticas o antiartísticas (Genette, 1997, p. 168).

Con esta definición ampliada de lo conceptual, todas las obras que hayan tenido una "recepción conceptual por parte del público, al que sorprendían por sus normas o hábitos" (Genette, 1997, p. 170), esto es, todas las obras que han propuesto un cambio de paradigma en el arte pueden ser consideradas conceptuales. A diferencia de Kosuth, que parece colocar lo conceptual del lado del autor —en la propuesta que el autor hace de que lo que presenta sea considerado arte-, Genette piensa en la recepción de la obra como una instancia que la constituye en su carácter mismo de conceptual, en tanto el funcionamiento conceptual de una obra, como él lo llama, es siempre en parte independiente de la intención del artista.

Pese a esta diferencia, creemos que la explicación de Genette acerca de las operaciones de reducción que tienen lugar en el arte conceptual resulta esclarecedora también para comprender la perspectiva de Kosuth y su obra. Dichas reducciones son (1) del objeto que se tiene enfrente al acto de presentarlo como obra de arte y (2) de dicho acto al concepto como el objeto ideal que le da sentido a la obra. Nuevamente, en Kosuth, estas dos reducciones parecen tener lugar en las intenciones del autor, mientras que para Genette se configuran en la recepción de la obra. Para él, "siempre es más o menos lícito recibir una obra ora en modo 'perceptivo' (...) ora en modo conceptual —remontándose del objeto al acto y del acto al concepto-, ora según alguna combinación de las dos actitudes de recepción” (Genette, 1997, p. 176).

Volviendo entonces a la argumentación de Kosuth, un punto muy importante que presenta en este artículo es la caracterización de la obra de arte como una proposición analítica, en el sentido kantiano o, más bien, siguiendo la interpretación que A. J. Ayer hace de la tesis kantiana. Allí se hace evidente la centralidad del autor en la caracterización del arte como conceptual en "Art after Philosophy". Enmarcándose en el universo terminológico kantiano, pero yendo también mucho más allá de él, afirma Kosuth que el arte - entendido como una proposición- no está afirmando nada acerca del mundo, y que por ello no tiene sentido que su contenido 
de verdad sea contrastado con los hechos empíricos. Cuando un artista presenta una obra, la proposición que está defendiendo es siempre "esto es arte", es decir, está proponiendo — desde la acción— una cierta definición de arte. Esta definición, esto es, la propuesta de que eso que se está presentando - una obra, una idea, un hecho, un objeto- es arte, no es verificable empíricamente, y ahí radica su carácter de juicio analítico o a priori.

Conviene que nos detengamos brevemente en este punto, en tanto pone de manifiesto una tensión crucial con la filosofía tal y como la comprendió Benjamin. Como ella, el arte renuncia a la representación del mundo, pero, a diferencia de ella, renuncia también a la exposición de toda verdad que no se refiera a sí misma. Siguiendo la argumentación de Kosuth, el arte no tendría ningún objeto más que sí mismo, mientras que la filosofía mantendría, aun a fuerza de modificarla muy marcadamente, una relación con el mundo, aunque no ya mediante su comprensión como un objeto sino, con Benjamin, en términos de una cierta tarea que es enunciada de formas diversas, ya como salvación de los fenómenos, ya como una "mostración" por medio del montaje.

La argumentación de Kosuth prosigue hacia una comprensión de la obra de arte como algo más relacionado con la función que con la apariencia o la forma. Si bien qué función proclama para el arte en la sociedad es algo que no se desprende de modo transparente del texto, hay algunas indicaciones que pueden ayudarnos a vislumbrar el rol que el arte podría cumplir: por un lado, Kosuth sostiene que la capacidad del arte para existir dependerá de que se abstenga de ofrecer un servicio - por ejemplo, decorar o entretener- Por otro lado, el arte deberá mantenerse alejado de los juicios filosóficos o, más específicamente, de comprometerse con una postura filosófica. Al mantenerse entonces al margen de funciones y posturas fijas, el arte será para Kosuth capaz de cumplir con una tarea que les estaba asignada otrora a la religión y a la filosofía, a saber, "satisfacer aquello que en otra época podría haber llamado 'las necesidades espirituales del hombre" (Kosuth, 1991, p. 24) en tanto el arte "lidia con el estado de cosas que están más allá de lo físico" (Kosuth, 1991, p. 24).

Sobre este punto, ligado a la función del arte, nos interesa hacer dos observaciones. En primer lugar, que al colocar al arte en una línea de continuidad con la religión y con la filosofía comprendida como metafísica, Kosuth corre el riesgo de acercarse a aquello que Benjamin llamará "teología del arte", al mantener al arte en una esfera de pureza religiosa, y al asignarle una función casi mítica. En este sentido, las afirmaciones de Genette nos parecen alojar una potencialidad mayor para comprender la función o las 
funciones posibles para el arte en nuestra época. Este autor pone el énfasis, hablando del gesto propio del arte conceptual, en que "el significado y la función de dicho gesto sigue siendo, por su parte, indefinido, abierto y suspendido como el de cualquier objeto estético (...). No sabemos exactamente qué quiso decir Duchamp" (Genette, 1997, p. 177). Como veremos en el próximo apartado, esta indefinición, esta falta de explicación o explicitación, es justamente, para Benjamin, especialmente en su análisis de la narración, el sitio donde se aloja la potencialidad de la obra, que se desplegará - $\mathrm{O}$ no- cuando encuentre un receptor que realice un trabajo activo de desciframiento. Genette parece dejar, tanto en la definición de qué sea el arte conceptual como con respecto a la función del arte, más lugar para el receptor que Kosuth, para quien el artista tiene aún una centralidad considerable.

Asimismo, y después de afirmaciones de corte más rupturista, ligadas a la filosofía contemporánea y marcadamente en contra de posturas nostálgicas acerca de algo así como "lo clásico", Kosuth parece recaer en algunos lugares comunes acerca de la función del arte, y con él de la filosofía y de la religión. La idea misma de unas "necesidades espirituales" y de aquello que "está más allá de lo físico" resultan al menos sorprendentes en pleno siglo xx. El diagnóstico acerca del fin de la filosofía, que el autor postula al comienzo del texto y que no queda del todo claro, en este escenario, se esclarece: si la filosofía es la filosofía de esa tradición, o más directamente, si la filosofía se identifica con la metafísica y con sistemas cerrados, entonces sí hay razones para proclamar su muerte (o su agonía) en el siglo xx. No obstante, la filosofía muta a lo largo de este siglo no sólo hacia un análisis del lenguaje, sino también — tanto en Europa como en Estados Unidos y en Latinoamérica- hacia un análisis político y social orientado hacia múltiples áreas, fenómenos y conflictos, entre los cuales los feminismos, las diferentes filosofías de la educación, los análisis sobre el arte o filosofías como la existencialista o la pragmatista son sólo algunos ejemplos. Kosuth, si bien parte de Wittgenstein y trabaja, posteriormente, con textos de Benjamin, no parece tener en cuenta, a la hora de argumentar, todo aquello que atraviesa a la filosofía una vez que esta abandona sus pretensiones clásicas, y que la reconfigura radicalmente: quizá, como veremos más adelante, esta reestructuración sea tan radical como la que significa para el arte la irrupción del arte conceptual, que el mismo Kosuth reconoce y celebra. Queda pendiente examinar un poco más a fondo por qué, tan alejado de aquellos que no llamarían arte al arte contemporáneo, Kosuth sí parece alinearse con aquellos que no llamarían filosofía a los desarrollos filosóficos del siglo xx. 


\section{Benjamin y Kosuth desafiando los límites disciplinares}

En su libro Calle de mano única Walter Benjamin experimenta con algunas de las propuestas que luego sistematizará en "El autor como productor", y activa, asimismo, algunas de las ideas que presenta en el libro sobre el Trauerspiel tras su necesaria modificación al calor de su despertar materialista ${ }^{12}$. De contenido vanguardista, el libro reúne textos breves de formato variado que, desde el humor, el análisis político, la descripción o la ironía abordan temas que, en muchos casos, quedan fuera de los análisis filosóficos tradicionales.

Sigfried Kracauer, en su reseña conjunta de este libro y El origen del Trauerspiel alemán, recupera muy apropiadamente la sugerente definición del filósofo como figura intermedia o habitante de dos mundos que Benjamin ofrece en el texto de su frustrada habilitación docente, esto es, el filósofo ocupando una posición intermedia entre el investigador y el artista (Kracauer, 1995, p. 264). Central para esta definición resulta, como mencionamos, la importancia brindada al modo de exposición, que en este caso arroja textos breves en los cuales, siguiendo a Kracauer, Benjamin expone la estructura discontinua del mundo, que experimenta cotidianamente frente al mito de la totalidad (que es expresado paradigmáticamente, en la filosofía, por el sistema).

A continuación, intentaremos caracterizar estas breves "instantáneas filosóficas” (Richter, 2010, p. 252), que Benjamin llamó renuentemente, como menciona en una carta a su amigo Gershom Sholem, "aforismos" (se refiere al libro como "Aphorismenbuch"), y que luego Adorno bautizó "Denkbilder", "imágenes de pensamiento", a partir de dos de sus rasgos principales: su alejamiento del concepto y su espacialidad.

El primer rasgo nos enfrenta ya radicalmente con una ruptura con la forma en que tradicionalmente se presenta el discurso filosófico, esto es, en torno a argumentos, exposiciones por pasos y explicaciones. Las Denkbilder,

${ }^{12}$ La relación entre alegoría y montaje resulta en este sentido central. Al respecto, ver García (2010) donde se explicitan las continuidades entre ambos conceptos (el trabajo con los fragmentos, el rechazo de la totalidad orgánica) sin desatender las diferencias, relacionadas en última instancia con algunos de los cambios que se introducen en la filosofía de Benjamin tras su acercamiento al marxismo. En un sentido similar Steiner (2002), al trabajar con la lectura benjaminiana de Goethe e incorporar para ello el artículo que Benjamin prepara sobre este autor para la Enciclopedia Soviética durante su estancia en Moscú, conecta de un modo muy esclarecedor algunos motivos anteriores a su encuentro con el marxismo y algunos posteriores, y de cuenta, como García, de algunas tensiones sin caer en la tentación de resolverlas. 
en cambio, rehúsan estas formas de presentación trabajando con el rodeo del que hablaba Benjamin en el Prólogo de su estudio sobre el Trauerspiel, y acercándose asimismo a la narración ${ }^{13}$.

En "El arte de narrar" Benjamin observa que "ya no nos llega ningún acontecimiento que esté libre de datos explicativos" (Benjamin, 2011, p. 163) y dice sobre la narración, oponiéndola fundamentalmente al discurso informativo de la prensa:

El mérito de la información pasa, en cuanto esta deja de ser novedad. Ella sólo vive en ese momento. Debe entregarse a él y explicarse sin perder tiempo. Pero con el relato sucede otra cosa: no se agota, sino que almacena la fuerza reunida en su interior y puede volver a desplegarla después de largo tiempo (Benjamin, 2011, p. 163).

Resulta clave, en este punto, el caso de la historia del rey egipcio Samético, de Heródoto, que trae Benjamin a colación para ilustrar esta fuerza propia de la narración. De ella dice:

De lo que no cabe duda es de que todos los periodistas la explicarían en un abrir y cerrar de ojos. Heródoto no la explica ni con una palabra. Su relato es el más seco. Por eso esta historia del antiguo Egipto puede provocar asombro y reflexión aún hoy, después de milenios (Benjamin, 2011, p. 164).

En un sentido contrario al de la información periodística, que "permanece ajena a la experiencia del receptor, cuanto más se le impone en la forma de explicaciones respecto de la cosa” (Weber, 2014, p. 513), el arte, la narración y las imágenes de pensamiento con las que Benjamin puebla su filosofía no pueden ser meramente digeridas o asimiladas. Estas vías de exposición, lejos de ser meras formas que se le imprimen a un determinado contenido - como si hubiera un mensaje que puede ser transmitido en tanto narración, a través de una pintura o mediante una explicación- proponen una experiencia.

En "Experiencia y pobreza", de 1933, cinco años después de la publicación de Calle de mano única, Benjamin diagnosticará una crisis de la experiencia [Erfahrung] en el mundo contemporáneo, ocasionada por los estragos de la guerra y el avance de la técnica. Esta crisis hace alusión a la imposibilidad de que las vivencias individuales sean elaboradas colectivamente por los sujetos, que ganan en información, pero pierden orientación en la vida. "No son ignorantes inexpertos" dirá Benjamin, "con frecuencia es posible decir todo lo contrario: lo han devorado todo, 'la cultura' y el hombre, y están sobresaturados y cansados” (Benjamin, 1982, p. 172).

${ }^{13}$ Sobre el motivo de la narración, central en la obra de Benjamin, ver Oyarzún Robles (2008), Gagnebin (1999) y Di Pego (2015). 
Proponemos pensar a las imágenes de pensamiento que Benjamin ofrece en Calle de mano única como tratando de proporcionar a los lectores una experiencia, al requerir de su parte un trabajo de elaboración del sentido, que no está dado ni simplemente oculto o velado. Para lograr esto, se alejan no sólo del modelo expositivo- deductivo de la ciencia, sino también de la unidad más propia del pensamiento filosófico en su formato tradicional, a saber, el concepto. Sobre este punto coinciden no sólo los lectores actuales de Benjamin, sino también sus contemporáneos. Adorno, por ejemplo, sostuvo que "en contraste con todos los otros filósofos... el pensamiento de Benjamin, como paradójico que pueda sonar, no era uno que tuviera lugar en los conceptos... Él abría aquello que no podía ser abierto como si tuviera una llave mágica" (Adorno, 2001, p. 29). Esta llave, que le permite a Benjamin abrir aquello que en conceptos no se muestra, es justamente, creemos, articular el pensamiento en imágenes [Bilder], aprovechando la potencia expresiva de la imagen como disparador, acercándose en este movimiento al lenguaje del arte y recuperando para la filosofía la atención a la exposición.

Este alejamiento del concepto es muy significativo, no sólo por su carácter de gesto rupturista con respecto a la tradición filosófica (y a la concepción, tan arraigada, del conocimiento como un cierto haber), sino también - y este punto no recibió, creemos, la atención debida - en lo que respecta al movimiento que el arte realiza en el siglo xx de acercamiento al concepto y de alejamiento del soporte de la imagen. Volveremos sobre este punto en las consideraciones finales del trabajo.

Ahora bien, lo que tiene lugar en y con las imágenes de pensamiento de Benjamin, a través de ellas, no es literatura sino filosofía, en tanto condensa en sus breves narraciones no sólo tópicos filosóficos, sino también un tratamiento de esos tópicos que no resigna rigurosidad. No se trata aquí de arte después de la filosofía, sino propiamente de filosofía después de la filosofía, aun cuando esa filosofía cuestione, como ha hecho más de una vez, su propia tradición.

El segundo rasgo que nos interesa destacar de las Denkbilder es la espacialidad que les es propia en su carácter de imágenes ${ }^{14}$. La presentación de razonamientos deductivos o la argumentación por pasos tiene, por su carácter progresivo, una cualidad temporal en la que los momentos se suceden

${ }^{14}$ Sobre este punto, Susan Sontag sostiene: "Los temas recurrentes de Benjamin son maneras de espacializar el mundo: por ejemplo, su noción de las ideas y las experiencias como ruinas. Comprender algo es comprender su topografía, saber cómo trazar su mapa. Y saber cómo perderse” (Sontag, 2007, p. 125). 
unos a otros de modo lineal ${ }^{15}$, y el pensamiento del lector es guiado hacia conclusiones o asociaciones ya recorridas previamente por el autor. Benjamin evita este modelo: en "Sombras breves", a su manera siempre críptica, lo deja claro: "lo que es decisivo no es la progresión de una cognición a otra, sino el salto o la grieta [Sprung] inherente a cualquier conocimiento mismo" (citado por Richter, 2010, pp. 264-265). Las imágenes de pensamiento, al trabajar visualmente, son capaces de generar yuxtaposiciones en un montaje que evita la progresión ${ }^{16}$, y que se hace patente especialmente en la disposición espacial de los textos en el libro que nos ocupa (ver fig. 1). Esta manera de presentar las ideas, si bien se presta, podría objetarse, a confusiones o malinterpretaciones, tiende, como la narración, a despertar en el lector un trabajo de elaboración que podría ser, justamente, la clave de salida de la crisis de la experiencia. Parafraseando a Genette, nunca sabemos exactamente qué quiso decir Benjamin. La idea misma de malinterpretación, en tanto presupone un contenido fijo (a modo de mensaje) que el texto representa y que se esconce, velado, tras su forma críptica, va en contra del motivo de la exposición tal y como aparece en Benjamin, como mencionamos anteriormente en relación con la forma alegórica.

También en este sentido se pronuncia Weigel, cuando afirma que:

En las imágenes de pensamiento resulta evidente que escritura y modos de pensar en Benjamin no pueden separarse, pero también que su manera de pensar en imágenes constituye no sólo la vía específica de su configuración teórica, sino también de su filosofía y de su escritura y, por último, que sus textos no pueden dividirse en forma y contenido. Mucho más puede extraerse todavía de las numerosas constelaciones de Leitmotive que forman sus textos, así como también puede descubrirse un modo particular de escribir logrado a partir de las tensiones entre la lengua poética y el metadiscurso conceptual, como si existiera un tercer elemento más allá de la oposición dualista entre literatura y filosofía (Weigel, 1999, p. 103).

Y es que la potencialidad de la forma de escritura que caracteriza Calle de mano única, y con la que Benjamin buscaba que la literatura, en sus pro-

${ }^{15}$ En este contexto es muy importante recordar la crítica a la ideología del progreso que llevará a cabo Benjamin en sus Tesis "Sobre el concepto de historia". En dicho texto, además de cuestionar la idea de progreso, Benjamin cuestiona la idea misma de historia del historicismo y su concepción del tiempo como homogéneo y vacío. Al respecto puede consultarse el estudio de Reyes Mate (2009).

${ }^{16}$ Esta forma de presentación de los textos, con la espacialidad que le es propia, encuentra ecos en varias ideas que Benjamin desarrolla en diferentes períodos. En torno al escrito sobre el Tranerspiel, por ejemplo, Benjamin se refiere al mosaico, en el que la individualidad de las piezas y la forma en que entran en relaciones entre sí son igualmente relevantes. Asimismo, y como ya mencionamos, el trabajo con el montaje y fundamentalmente con la idea de "mostrar" en lugar de "decir" es central en su Obra de los pasajes. 
pias palabras, se acercara a formatos "que se corresponden mejor con su influencia en las comunidades activas que el pretencioso gesto universal del libro" (Benjamin, 2014, p. 43), lejos de modificar únicamente a la literatura, transforma también a la filosofía, que encuentra allí, citando la reseña de Adorno, el modo de "poner en movimiento al pensamiento que en su expresión tradicional y conceptual parece rígido, convencional y envejecido" (Adorno, 2001, p. 29). Y esta escritura, que quería salirse de los formatos clásicos y tener influencia en las comunidades activas, fue puesta a circular en 1994 por las calles de Berlín por un artista conceptual: nada menos que Joseph Kosuth.

Aun "después de la filosofía”, la obra de este artista se caracteriza por su estrecha relación con la reflexión filosófica, de modo tan radical que podríamos imaginarnos a Kosuth escribiendo un artículo que, en lugar de "Art after Philosophy" se titule "Philosophy after Art", en el sentido en que Danto escribe acerca del fin del arte en $1984^{17}$.

La exposición en la que Benjamin fue protagonista se llamó Berliner Chronik. Si bien al tratarse de una instalación efímera no es posible reconstruirla en su totalidad ${ }^{18}$, tenemos noticia, a partir de algunas notas publicadas en el periódico alemán de tirada diaria Die Tageszeitung (taz) — que participó en la organización de la instalación-, de algunas de las acciones que involucró.

A partir del 7 de julio de 1994, Kosuth citó fragmentos de obras de Benjamin en las páginas de este mismo diario durante siete días, así como intervino también otras áreas de la comunicación (televisión, cine, teatro, arquitectura, arte e internet ${ }^{19}$ ) con pasajes de la obra del filósofo: en el canal de televisión B1 fueron vistas citas de Benjamin durante diez días; hasta el 31 de julio fue proyectado un tráiler (cuyo contenido hoy se desconoce) en nueve cines de Berlín; por cuatro días una inscripción permaneció instalada en una obra en construcción en el centro de la ciudad.

17 “¿Qué pasa con el arte después del fin del arte, donde con 'arte después del fin del arte’, significo 'tras el ascenso a la propia reflexión filosófica'?” (Danto, 2010, p. 36).

${ }^{18}$ Nos hemos puesto en contacto con Kunst-werke, el Instituto de Arte Contemporáneo que junto con Kosuth organizó la instalación, cuya colaboración en esta investigación agradecemos, y aun así no fue posible encontrar más información sobre qué otras frases de Benjamin fueron mostradas en los diferentes medios. El libro que acompañó la exposición (Klaus Biesenbach y Harald Fricke (Ed.): Joseph Kosuth. Berlin Chronicle - A Temporary Media Monument for Walter Benjamin. Berlin: KW Institute for Contemporary Art, 1994) es asimismo casi imposible de conseguir.

${ }^{19}$ Según una nota publicada en taz el 4 de julio de 1994 y disponible en la página web del diario. 
Berliner Chronik es, asimismo, el título de un texto de Benjamin de 1932, y el hecho de que Kosuth titule así su obra no deja de resultar significativo. Y es que la Crónica de Berlín de Benjamin es una exploración de la propia memoria y de la forma en que esta trabaja espacialmente, atendiendo a imágenes, lugares y ruinas más que a líneas temporales. Benjamin mismo da cuenta del tipo de ejercicio al que se entrega en este texto distanciándolo de la autobiografía, en tanto la misma "se da siempre en relación al tiempo, a su decurso y, finalmente, lo que constituye el fluir continuo de la vida. Pero aquí se trata de un espacio, sólo de instantes, de lo discontinuo" (Benjamin, 2017, p. 647).

El carácter topográfico de los recuerdos que tejen el relato y la forma en que la ciudad emerge menos como paisaje o escenografía que como personaje hacen que edificios, obras en construcción y periódicos resulten medios más que apropiados para situar la escritura de Benjamin, que se origina, en alguna medida, en la experiencia de habitar la ciudad. Consciente de la importancia de los lugares, y típicamente de las ciudades, en su vida, Benjamin jugaba con la idea de "articular gráficamente en un mapa el espacio de la vida" (Benjamin, 2017, p. 621), como si la misma se desplegara más en las superficies habitadas que en el continuo temporal. La presencia de Proust, a quien Benjamin se refiere en este texto como uno de sus guías (Benjamin, 2017, pp. 622-623), es innegable, tanto en la atención a los lugares como en la relación entre la memoria y la imagen y en la destrucción de la idea de tiempo lineal que opera a la base de la ideología del progreso. El trabajo con la imagen, al que nos referimos anteriormente, y el mostrar o exponer en lugar de brindar explicaciones o representar cadenas deductivas encuentra en este guía - de quien el berlinés fuera también traductor- un antecedente importante. En palabras del mismo Benjamin: "el procedimiento empleado por Proust ya no es el modelo de la reflexión, sino el hacer presente en cuanto tal" (Benjamin, 2007, p. 327).

Berliner Chronik de Kosuth se presenta, en varios aspectos, como una materialización de las ideas — tanto de Benjamin como de Kosuth- que venimos explorando. Por un lado, y aunque posee un soporte físico y visual, no es posible hacer de esta instalación una experiencia estética tradicional, en la que se aprecian las características relativas al aspecto de la obra (o, en palabras de Genette, la obra no invita a una recepción estética). La desmaterialización del arte, si bien no completamente, hace una cierta entrada aquí: al menos ni la imagen, en sentido tradicional, ni el objeto están presentes y, en su lugar, aparece el lenguaje. Sin embargo, desde la perspectiva de la filosofía este irrumpir en el espacio de la ciudad puede ser entendido, 
contrariamente, como una cierta materialización, a través de la cual textos filosóficos pueden encontrar receptores antes impensados o situaciones de recepción diferentes de las que propone el formato tradicional del libro, especialmente dada la posibilidad de una recepción colectiva (en el caso de las inscripciones en edificios, en obras y en el cine o el teatro), y de una recepción en la dispersión.

La propuesta de Kosuth, en su carácter de obra conceptual, está diciendo, "esto es arte", y eso que es arte no es otra cosa que filosofía. La tradición con la que se entabla una relación en este caso no es la historia del arte sino la del pensamiento filosófico.

Aun así, en su homenaje al "Berlín vivido" (Benjamin, 2017, p. 622) de Benjamin, Kosuth elige una frase que se refiere, ahora sí, al arte y a su lugar en la sociedad. Así, en el frente del edificio de Kunst-Werke, el Instituto de Arte Contemporáneo junto al cual organizó la intervención, el artista coloca una cita de "El autor como productor", que permanece allí hasta la actualidad (ver fig. 2):

„Man kann erklären: ein Werk, das die richtige Tendenz aufweist, braucht keine weitere Qualität aufzuweisen. Man kann auch dekretieren: ein Werk, das die richtige Tendenz aufweist, muss notwendig jede sonstige Qualität aufweisen" [Se puede decretar, pudiendo declararse que una obra con la tendencia correcta no necesita de otra calidad. Y también puede decretarse que una obra con la tendencia correcta ha de tener necesariamente todas las restantes calidades] (Benjamin, 2009, p. 298).

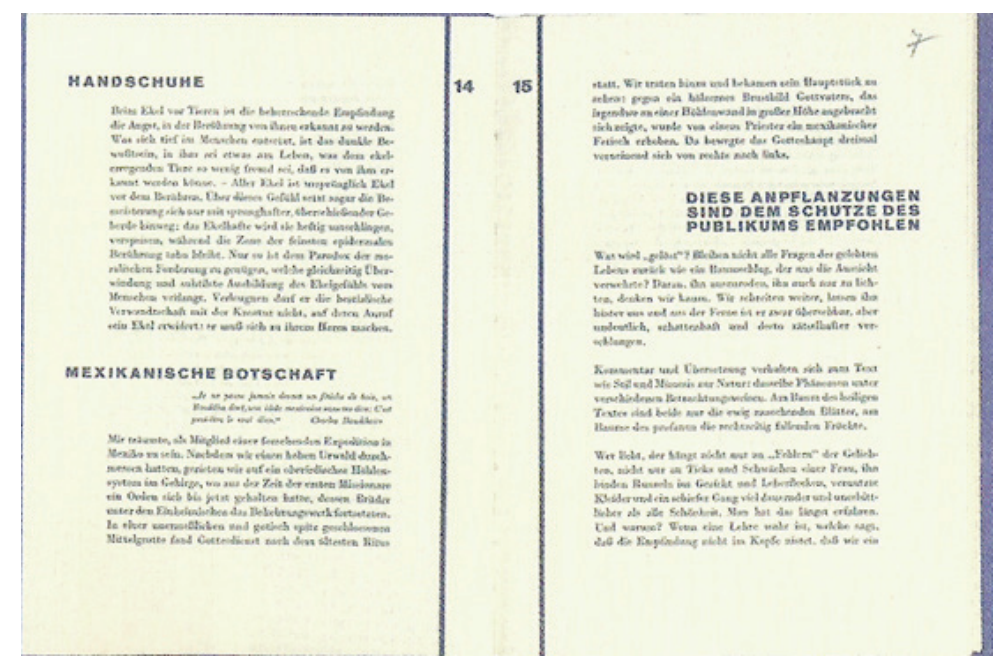

Figura 1. La edición original de Calle de mano única. La forma de colocar los textos buscaba recrear el encuentro del habitante de la ciudad con los carteles publicitarios. Las líneas del centro emulan el trazado de una calle. 


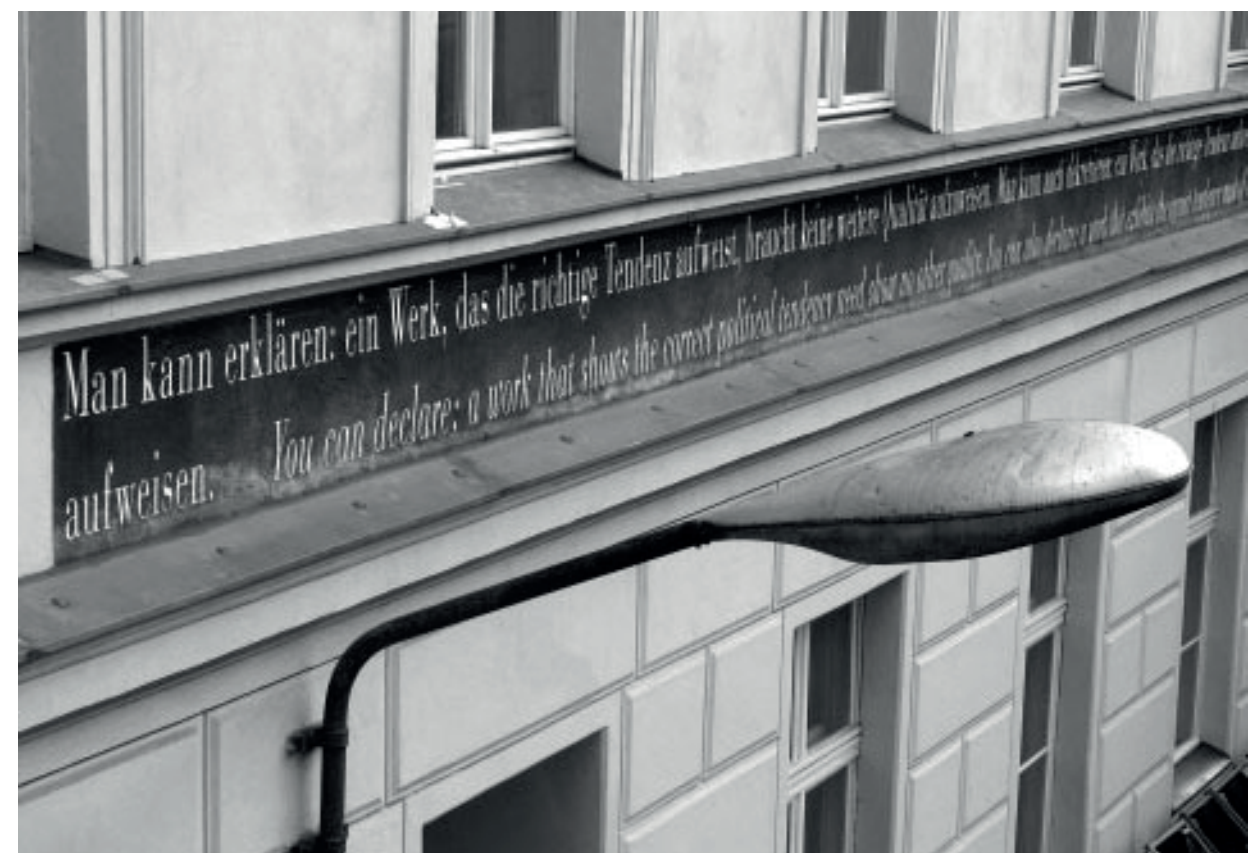

Figura 2. Instalación de Joseph Kosuth, BERLINER CHRONIK, 1994.

Esta afirmación de Benjamin se refiere, como ya comentamos, a sus reflexiones sobre el lugar del arte en la sociedad y específicamente sobre su posibilidad de incidir en lo social de una manera políticamente justa. En dicho marco, Benjamin concluye que el autor, entendido como productor, debe centrarse en modificar su mismo proceso productivo, e indica varias tareas que Kosuth parece tomarse en serio aquí: descreer de la dicotomía estéril que se tensa entre la imagen y el lenguaje, modificar los medios de producción en lugar de limitarse a alimentarlos, cambiar la relación con los posibles receptores de la obra, y repensar el modo en que forma y contenido, o tendencia política y calidad, se relacionan en una obra.

Asimismo, Kosuth parece llevar más allá, en su obra homenaje, la tendencia que encuentra Benjamin en su época respecto de la escritura en Calle de mano única. Dos fragmentos de este libro resultan muy claros en este sentido. El primero sostiene que "la eficacia literaria trascendente (...) debe cultivar los discretos formatos del volante, el folleto, el artículo de revista y el cartel publicitario" (Benjamin, 2014, p. 43). Benjamin le pide a la literatura que se mude a formatos más propios de la época contemporánea, y en este caso quien le responde es un artista conceptual, llevando sus textos a 
la fachada de un edificio, a un periódico o a la televisión en una operación caracterizada por la cita.

El segundo fragmento es el siguiente:

La escritura, que había encontrado asilo en el libro impreso, donde llevaba adelante una existencia autónoma, es sacada a la calle y sometida a las brutales heteronomías del caos económico. Esa es la severa escolarización de su nueva forma. Si hace siglos empezó paulatinamente a inclinarse, pasando de la inscripción vertical a la oblicua letra a mano que reposa sobre atriles, para por último recostarse en la letra impresa, empieza ahora con la misma lentitud a levantarse otra vez del piso. Ya el periódico se lee más en vertical que en horizontal, mientras que el cine y la publicidad empujan la letra hacia la verticalidad dictatorial. Y antes de que un contemporáneo llegue a abrir un libro ha caído sobre sus ojos un torbellino tan denso de letras de moldes versátiles, coloridas y contendientes, que las chances de penetrar en la arcaica tranquilidad del libro han quedado disminuidas. Los enjambres de langostas escritas, que hoy ya les ensombrecen a los habitantes de las metrópolis el sol del supuesto espíritu, se harán más densos con cada año venidero (Benjamin, 2014, p. 66).

En este segundo texto, Benjamin narra la historia de la escritura, que va moviéndose de formatos y que estaría, en el siglo xx, volviendo al soporte vertical que le diera asilo antes de la invención del libro como objeto. La escritura "es sacada a la calle", dice Benjamin, refiriéndose a los carteles publicitarios cuyo análisis le es tan propio. La relación entre la escritura y la ciudad, presente aquí, se complejiza justo en la encrucijada (o en la esquina) entre Benjamin y Kosuth: la ciudad, que en Calle de mano única, como se expuso, hace su aparición y puebla el libro, dotándolo no sólo de una calle sino también de un montaje de edificios, pasajes y mensajes que emulan la forma de recepción propia de la experiencia urbana, esa ciudad, entonces, se ve en el caso de Kosuth intervenida por el lenguaje: es el libro el que le presta ahora a la ciudad su propio rostro.

En el gesto artístico de Kosuth, en este sacar la escritura a la calle, textos de Benjamin irrumpen en los años noventa en las calles de la gran metrópoli que es Berlín, lo que genera al menos dos rupturas. Por un lado, textos no publicitarios le hablan al habitante de la ciudad sin un objetivo comercial, ni informativo, ni ideológico a la vista, y sin siquiera parecer tener un objetivo específico. En este sentido, la lógica de la publicidad es subvertida, y una intervención artística irrumpe el espacio público sin una agenda clara. Pero el tipo de texto, su contenido temático o su intención no son lo único que aparta este gesto artístico de la publicidad: además de filosóficos, los textos son inactuales. A diferencia de los carteles publicitarios, y de la información, que cambian rápidamente y buscan una efectividad inmediata, las frases de Benjamin — 60 años después de su momento original de enunciación- significan en algún sentido una cierta experiencia con el pasado. 
Asimismo, la elección de la cita de "El autor como productor" parece materializar las ideas de Kosuth que analizamos en su escrito: el arte conceptual se refiere a sí mismo, y habla en este caso a través de Benjamin de su propia relación con la realidad social. Su proposición dice algo acerca del arte, porque en su etapa conceptual el arte se convierte en tema para sí mismo. Sin embargo, la elección del texto que Benjamin redacta con el fin de poner en cuestión el lugar de los intelectuales y artistas y de pensar de qué manera pueden, el arte o la filosofía, incidir de una manera justa en el ambiente público, da cuenta de la intención de Kosuth de posibilitar una cierta experiencia política, experiencia que le propone al paseante el arte, después de la filosofía.

Otra de las citas que eligió Kosuth, y que apareció en el diario Die Tageszeitung, está extraída de "Sobre algunos motivos en Baudelaire". Benjamin se refiere allí a la forma de circulación de la información, tal y como se da en los periódicos, y a la que distingue, como mencionamos, de la narración oral que la precedió, poniendo a jugar dos de los motivos centrales de su pensamiento: narración y experiencia. La cita es: "Todas esas formas se apartan igualmente por su parte de la narración, que es una de las formas más antiguas de comunicación que se conoce” (Benjamin, 2008, p. 212) [„Alle diese Formen heben sich ihrerseits von der Erzählung ab; sie ist eine der ältesten Formen der Mitteilung "].

Conviene reponer algo del contexto: inmediatamente antes de la frase citada dice Benjamin en su escrito sobre Baudelaire: "En la sustitución de la antigua relación por la ya moderna información, y de la información por la sensación, se refleja la atrofia creciente y actual de la experiencia" (Benjamin, 2008, p. 212).

En el mismo sentido, y sólo unas líneas después de la citada frase, dice Benjamin:

La obra en ocho volúmenes de Proust nos da idea de qué disposiciones eran precisas para restaurar en el presente la desgastada figura del narrador. Proust la emprendió con magnífica coherencia, y así, desde el comienzo, acometió una tarea elemental: componer un relato de la propia infancia (Benjamin, 2008, p. 212).

Kosuth explora, con toda su producción pero específicamente con la instalación que analizamos aquí, las posibilidades del arte de interpelar en el contexto de la atrofia de la experiencia y de las modificaciones que la técnica y la vida en las ciudades imponen a prácticas que tradicionalmente eran constitutivas de la vida en comunidad. Como Benjamin, y con Benjamin, el artista conceptual se hace eco del aislamiento y la falta de unidad y de sentido que caracteriza nuestra vida, y se propone posibilitar una expe- 
riencia en la era de su crisis, pero la experiencia posible será, lejos de toda nostalgia por formas de vida pasadas, fragmentaria.

No en vano nombra Kosuth a su homenaje "Berliner Chronik", en clara referencia a la obra en la que Benjamin, siguiendo las huellas de Proust, se propone componer su propia infancia desatendiendo cronologías y teleologías que falsean el recuerdo, a través de la fragmentación y el montaje que le son propios a la memoria.

\section{Consideraciones finales}

Entre las obras de estos dos autores es posible generar, como tratamos de mostrar en este trabajo, un cierto campo de tensión en el que se inscriben interesantes puntos de contacto y algunos cruces llamativos.

Ambos han intentado, desde sus ideas y desde su obra, traspasar los límites que los campos estancos imponían a su producción con el objetivo de ofrecer un camino de renovación en sus áreas de desarrollo, y ambos lo han hecho menos por el simple placer de explorar que movidos por la conciencia de una ruptura con la tradición, y de vivir en un siglo que clama por nuevas formas de interpelar. Ambos han cuestionado, con su trabajo, la división tajante entre lenguaje e imagen bajo el régimen de la cual vivimos, y ambos han logrado construir una obra que constituyó un cierto cambio de paradigma en su campo. Asimismo, los dos investigan la naturaleza de su área propia de producción y lo hacen menos escribiendo teoría del arte o metafilosofía que desde la experimentación misma. En efecto, ambos insisten en sus textos teóricos en la importancia de la innovación técnica desde la producción misma, y son reacios a proponer cambios que se acoten al contenido de la obra, cuestionando aquellas producciones que resultan innovadoras o revolucionarias desde su contenido - esto es, desde aquello que dicen- sin cuestionar su forma ni su técnica, ya sea de producción o de circulación. Para Kosuth, mientras hagamos pinturas estamos aceptando mucho más sobre el arte de lo que podamos cuestionar con el contenido de nuestras pinturas (Kosuth, 1991, p. 18). En Benjamin, mientras que los filósofos no atiendan a la cuestión de la exposición y se limiten al desarrollo conceptual y a la creación de sistemas, y mientras que no desafíen el limitado campo al que fueron restringidos, estarán aceptando de la tradición de la filosofía mucho más de lo que pueden cuestionar en el seno mismo de sus argumentaciones o en la elección de los temas. 
En palabras de Benjamin, mientras la filosofía esté determinada por "el concepto decimonónico de sistema” (Benjamin, 2010, p. 224),

corre el peligro de acomodarse a un sincretismo que intente atrapar la verdad en una tela de araña tendida entre distintos conocimientos, como si aquélla viniera volando de fuera. (...) Si la filosofía, no en cuanto introducción mediatizadora, sino en cuanto exposición de la verdad, quiere conservar la ley de su forma, tiene que conceder la correspondiente importancia al ejercicio mismo de esta forma, pero no a su anticipación en el sistema (Benjamin, 2010, p. 224).

Más allá de estas coincidencias, también hay cruces significativos que demarcan tensiones complejas entre el arte y la filosofía: en Kosuth el arte se desmaterializa y elimina la visualidad, mientras que en Benjamin la filosofía intenta volverse material y trabajar visualmente. Como menciona Lindner, "en ocasión del trabajo con Dirección única, Benjamin habló de la concreción extrema a la cual aspiraba" (Lindner, 2014, p. 68). Esta concreción, siempre en tensión con la forma más tradicional de filosofar, esto es, la reflexión abstracta que tiende a la universalización, adquiere en el libro que tratamos aquí la forma de un montaje, es decir, de una construcción. Así, imagen y construcción, con su espacialidad propia, encuentran sitio en la filosofía, donde tradicionalmente no es admitida ninguna corporalidad.

Esta cierta encarnación de la filosofía no es un detalle menor, en la medida en que configura un espacio de cruce con el campo artístico, y específicamente con la obra de Kosuth, en tanto mientras que esta última busca huir de los anclajes físicos tradicionales y redefenir el arte en función de su relación con el concepto, la filosofía reconoce las limitaciones propias del trabajo conceptual y busca nuevas posibilidades de decir. Paradójicamente, y como mencionamos, en el proceso de desmaterialización del arte, en el caso concreto de la obra de Kosuth que analizamos aquí, la filosofía encuentra espacio para operar una forma de materialización que le permite impactar en la ciudad de una forma a la que el libro no puede aspirar.

Asimismo, mientras Kosuth da cuenta del fin de la filosofía en su forma tradicional (a la vez que encuentra modos de darle lugar en la esfera pública), Benjamin tematiza muy claramente la muerte del aura y, con ella, de la forma tradicional de arte, y da cuenta de procesos cuya prolongación es el surgimiento del arte conceptual tal y como lo presenta Kosuth.

"La pregunta filosófica sobre la naturaleza del arte surgió dentro del arte", dice Danto, "cuando los artistas insistieron, presionaron contra los límites (...) y descubrieron que éstos cedían. (...) Y aquello que borraron nos ha dejado en la situación en la que nos encontramos hoy" (Danto, 2010, p. 36). Como en el arte, en la filosofía el juego con el límite, contra 
el límite y más allá del límite, como lo supieron Wittgenstein y Benjamin ${ }^{20}$, es una estrategia de escape cuando los paradigmas sofocan. Y así como Kosuth sostiene que después de Duchamp el arte comienza a hablar otro lenguaje, podríamos decir de Benjamin que le da a la filosofía la posibilidad de hacer lo mismo, cuestionando, como él mismo plantea en "El autor como productor", la oposición entre imagen y lenguaje.

Finalmente, el fin de la filosofía y el comienzo del arte, del que hablaba Kosuth, podría describirse también como un "fin del arte y comienzo de la filosofía” en los términos de Danto (2010) o quizá, más precisamente, como el ocaso tanto del arte cuanto de la filosofía como compartimentos estancos y su conversión en espacios nuevos, indefinibles y, por eso, fascinantes, en los que se "renuevan las formas de preguntar, traducir y trabajar con lo incomprensible o lo sorprendente" (García Canclini, 2010, p. 47). Al fin y al cabo, como dijera Benjamin, "una obra significativa o funda el género como tal o lo supera, y en las perfectas se unen ambas cosas" (Benjamin, 2010, p. 242).

\section{Bibliografía}

Abadi, F., "La ampliación del concepto de experiencia en Benjamin: de Kant al surrealismo" en Eikasia, No 67, 2015, pp. 193-211. Adorno, T., "Dirección única de Benjamin" en Adorno, T., Sobre Walter Benjamin. Madrid: Cátedra, 2001, pp. 28-34.

Benjamin, W., "Experiencia y pobreza" en Benjamin, W., Discursos interrumpidos I. Madrid: Taurus, 1982, pp. 165-173.

Benjamin, W., "Hacia la imagen de Proust" en Benjamin, W., Obras II.1. Madrid: Abada, 2007, pp. 317-331.

Benjamin, W., "Sobre algunos motivos en Baudelaire" en Benjamin, W., Obras I.2. Madrid: Abada, 2008, pp. 205-260.

Benjamin, W., "El autor como productor" en Benjamin, W., Obras II.2. Madrid: Abada, 2009, pp. 297- 315.

${ }^{20}$ Si bien Benjamin y Wittgenstein fueron contemporáneos, no tuvieron intercambios ni hay registros de que se hayan conocido ni leído. Aun así, la afinidad entre sus filosofías fue advertida ya en los años 60 por Adorno (al respecto ver su Teoría estética, publicada como es sabido póstumamente, en 1970). Sobre posibles puentes entre el pensamiento de estos dos grandes filósofos ver Cavell (1999) y Gabrielli (2004). En español puede consultarse Delgado Rojo (2015). 
Benjamin, W., El origen del Trauerspiel alemán en Benjamin, W., Obras I.1. Madrid: Abada, 2010, pp. 217-459.

Benjamin, W., Denkbilder. Epifanías en viajes. Buenos Aires: El cuenco de plata, 2011.

Benjamin, W., Obra de los pasajes en Benjamin, W., Obras V.I. Madrid: Abada, 2013.

Benjamin, W., Calle de mano única. Buenos Aires: El cuenco de plata, 2014. Benjamin, W., "Crónica de Berlín" en Benjamin, W., Obras VI. Madrid: Abada, 2017, pp. 619-684.

Buchloh, B., "Conceptual Art 1962-1969. From the Aesthetic of Administration to the Critique of Institutions" en October, Vol. 55, Winter, 1990, pp. 105-143. https://doi.org/10.2307/778941

Cavell, S., "Benjamin and Wittgenstein: Signals and Affinities" en Critical Inquiry, Vol. 25, No. 2, "Angelus Novus": Perspectives on Walter Benjamin (Winter, 1999), pp. 235-246. https://doi.org/10.1086/448918

Danto, A., Después del fin del arte: el arte contemporáneo y el linde de la historia. Madrid: Paidós, 2010.

Delgado Rojo, J. L., "Benjamin y Wittgenstein. Una aproximación morfológica” en Agora. Papeles de filosofía, Vol. 34, No 1, 2015, pp. 33-57. https://doi.org/10.15304/ag.34.1.1664

Di Pego, A., "La ambivalencia de la narración en Walter Benjamin”, en Naishtat, F., Gallegos, E. y Xébenes, Z. (eds.), Ráfagas de dirección múltiple. Abordajes de Walter Benjamin. México: Universidad Autónoma Metropolitana - Unidad Cuajimalpa, 2015, pp. 141-167.

Espinosa, L., "Figuras de la crítica en Walter Benjamin: del romanticismo alemán a Charles Baudelaire" en Alpha, No 45, 2017, pp. 47-58. https://doi.org/10.4067/S0718-22012017000200047

Gabrielli, P., Sinn und Bild bei Wittgenstein und Benjamin. Bern: Peter Lang, 2004.

Gagnebin, J. M., História e narração em Walter Benjamin. São Paulo: Perspectiva, 1999.

Gagnebin, J. M., "Do conceito de Darstellung em Walter Benjamin ou verdade e beleza" en Kriterion, Belo Horizonte, $\mathrm{N}^{\mathrm{o}} 112$, 2005, pp. 183190. https://doi.org/10.1590/S0100-512X2005000200004

García, L., "Alegoría y montaje. El trabajo del fragmento en Walter Benjamin" en Constelaciones. Revista de Teoría Crítica. N ${ }^{o}$ 2, 2010, pp. 158-185.

García Canclini, N., La sociedad sin relato. Antropología y estética de la inminencia. Montevideo: Katz Editores, 2010. https://doi.org/10.2307/j. $\underline{\mathrm{ctvm} 7 \mathrm{bcb} 0}$ 
Genette, G., La obra del arte. Buenos Aires: Lumen, 1997.

Guasch, A. M., El arte último del siglo XX. Del posminimalismo a lo multicultural. Madrid: Alianza, 2001.

Hillach, A., "Imagen dialéctica” en Opitz, M. y Wizisla, E., Conceptos de Walter Benjamin. Buenos Aires, Las cuarenta, 2014, pp. 643-708.

Holz, H., "Idea" en Opitz, M. y Wizisla, E., Conceptos de Walter Benjamin. Buenos Aires, Las cuarenta, 2014, pp. 591-641.

Kracauer, S., "On the writings of Walter Benjamin" en Kracauer, S., The mass ornament. Weimar essays. Harvard University Press, 1995, pp. 259-264.

Kosuth, J., “Art after philosophy” en Kosuth, J., Art after Philosophy and After. Collected Writings 1966-1990. The MIT Press, 1991.

Laddaga, R., Estética de la emergencia. Buenos Aires: Adriana Hidalgo Editora, 2006.

Lindner, “Alegoría” en Opitz, M. y Wizisla, E., Conceptos de Walter Benjamin. Buenos Aires, Las cuarenta, 2014, pp. 17-82.

Oyarzún Robles, P., "Introducción”, en Benjamin, W., El narrador. Santiago de Chile, Metales pesados, 2008, pp. 7-52.

Reyes Mate, M., Medianoche en la historia. Comentarios a las tesis de Walter Benjamin "Sobre el concepto de historia". Madrid: Trotta, 2009.

Richter, G., "Una cuestión de distancia. La calle de dirección única de Benjamin a través de los pasajes" en Uslengui, A. (comp.), Walter Benjamin: culturas de la imagen. Buenos Aires: Eterna cadencia, 2010, pp. 237-282.

Sontag, S., Bajo el signo de Saturno. Barcelona: De bolsillo, 2007.

Steiner, U., “,Das Höchste wäre: zu begreifen, dass alles Factische schon Theorie ist". Walter Benjamin liest Goethe" en Zeitschrift für deutsche Philologie, 121. Band, 2002, pp. 265-284.

Weber, T., "Experiencia” en Opitz, M. y Wizisla, E., Conceptos de Walter Benjamin. Buenos Aires, Las cuarenta, 2014, pp. 479- 525.

Weigel, S., Cuerpo, imagen y espacio en Walter Benjamin. Una relectura. Buenos Aires: Paidós, 1999.

Zumbusch, C., Wissenschaft in Bildern. Symbol und dialektisches Bild in Aby Warburgs MnemosyneAtlas und Walter Benjamins Passagen-Werk. Berlin: Akademie Verlag, 2004. 